\title{
A NEW VARIETY of DRosera SPATULATA (DRoseraceae) FROM SARAWAK, BORNEO
}

\author{
AndREAS Fleischmann • LMU Munich, Systematic Botany and Mycology • Menzinger Strasse \\ 67・D-80638 Munich・Germany•fleischmann@lrz.uni-muenchen.de \\ CH'IEN C. LEE • Forest Research Center, Sarawak Forestry • Km 10, Jalan Stephen Kalong \\ Ningkan • 93250 Kuching $\bullet$ Sarawak $\bullet$ Malaysia
}

Keywords: New taxa: Borneo, Drosera spatulata.

Received: 2 January 2008

\section{Introduction}

The Bako National Park (Taman Negara Bako) was founded in 1957, making it the oldest national park in Sarawak. It covers an area of 2.727 ha (6.738 acres) at the tip of the Muara Tebas Peninsula (Good, 1988). This rather small national park is familiar to many carnivorous plant enthusiasts due to the various species of Nepenthes that grow within it, and its close proximity to Kuching, the state capital.

The majority of the park is situated on a relatively flat-topped sandstone plateau (the socalled "Bako Sandstones" of possible Eocene to early Miocene age), which slopes from over 250 $\mathrm{m}$ a.s.l. in the south to $60 \mathrm{~m}$ a.s.l. in the north, and forms vertical cliffs along the coastline (Hazebroek \& Morshidi 2005; Johansson 1999; Tan 1993).

On the Bako Plateau a small, deeply red coloured Drosera can be found in great abundance. This plant entered cultivation in Europe and the US in the early 1980s under the name "Drosera spec. 8 Borneo" (Weiner 1982). The morphological characters of this plant are stable throughout its range and are maintained in cultivation under artificial conditions. Thus the diminutive habit of the plant and the few-flowered inflorescence seem to represent genetically fixed characters, and are not environmentally induced growth modifications caused by the harsh conditions of its natural habitat. The plant's range is disjunct from known locations of "typical" D. spatulata, therefore we propose the rank of variety for this new taxon.

\section{Latin Description and Specimens Examined}

Drosera spatulata Labill. var. bakoensis A. Fleischm. \& Chi. C. Lee var. nova.

Var. D. spatulata Labill. sed inflorescentia breviore 1-3(5)-flora, folia parva 3-7(10) mm longa, stipulae c. $1 \mathrm{~mm}$ longae, pedunculi, pedicelli et sepala pauce glanduloso-puberuli.

Typus: MALAYSIA, Borneo, Sarawak, Bako National Park: Telok Pandan path, c. 90 m [300'], coll. 4.5.1959, J. Carrick \& I.C. Enoch JC/473 (SAR!).

Additional material examined:

Drosera spatulata var. bakoensis

MALAYSIA. Sarawak, Bako National Park: Pedang, 90 m (300'), coll. 22.4.1959, J. Carrick \& I.C. Enoch JC/49 (SAR!); Teluk Assam, heath woodland, 120 m (400'), coll. 17.5.1955, J. T. Pursoglow, P.4926 and P.4927 (spirit material) (SAR!); Lintang path, sides of paths in open places free of litter, especially damp places, acid soil, coll. 4.6.1963 P.S. Ashton, S.17920, as D. burmannii Vahl (SAR!). 
Rosetted perennial, rosette diam. 1.5-2.0 cm. Leaf petiolate, 3-7(10) $\mathrm{mm}$ long, spatulate in outline, 3-nerved. Petiole cuneate, 1.5-4.0 mm long, ca. $0.2 \mathrm{~mm}$ wide at base to $1 \mathrm{~mm}$ wide at upper end; lower surface sparsely covered with white appressed hairs, upper surface glabrous. Lamina rotundate to spatulate, 1.5-3.0 mm long, 1.5-2.5 mm wide, upper surface covered with carnivorous glands, marginal glands enlarged (ca. $2 \mathrm{~mm}$ long), with elongate head; leaf lower surface sparsely covered with translucent short-stalked glands. Stipule papery, white translucent (drying brown), 3-laciniate, middle lobe broadly triangular, ca. $1 \mathrm{~mm}$ long and ca. $0.3 \mathrm{~mm}$ wide, apex bifid or irregularly dissected, lateral lobes narrowly triangular (to fimbriate), $1.5-1.7 \mathrm{~mm}$ long and ca. $0.1 \mathrm{~mm}$ wide at the base. Inflorescences 1-6, 1-sided racemes, scape 2-6(7) cm tall, 1-3(5)-flowered, peduncle filiform, terete, to $0.2 \mathrm{~mm}$ in diam., base slightly ascending, upper part of peduncle with sparse cover of short-stalked glandular hairs, lower part and peduncle base glabrous. Pedicel terete, 1.2-2.0 $\mathrm{mm}$ long, to $0.2 \mathrm{~mm}$ in diam., sparsely covered with shortstalked glandular hairs. Bracts subulate, 1.0-1.5 mm long, 0.1-0.2 mm wide, covered with few short-stalked glandular hairs; lowermost flower usually without bract, upper flowers subtended by a bract, topmost flower (or single flower on a 1-flowered scape) subtended by 2 bracts, usually with relics of an aborted terminal flower subtended by the above bract. Calyx subcampanulate, sparsely glandular. Sepals 5, elliptic to narrowly obovate with apex acute or, 2.5-3.0 mm long, 0.8-1.5 mm wide, glabrous or covered with very few short-stalked translucent glands, sepa1s slightly reflexed in fruit. Petals 5, elliptic to narrowly obovate, margins involute, apex subacute or slightly crenulate, 5-6 mm long, up to $3 \mathrm{~mm}$ wide, pale pink. Anthers 5, filaments curved, cuneate, pollen yellow. Styles 3, divided to the base, style segments entire or rarely bifid, translucent white to bright pink, stigmatic tips cylindrical, surface smooth or minutely papillate. Ovary 3-partite, subglobose, yellowish green. Seed black, ellipsoid to cylindrical, 0.4-0.5 mm long and 0.2-0.25 mm wide, testa reticulate (see Figure 1).

\section{Distribution, Habitat, and Ecology}

Drosera spatulata var. bakoensis is separated biogeographically from all known populations of D. spatulata var. spatulata by several hundred kilometres ${ }^{1}$. It is endemic to the Muara Tebas Peninsular in the Kuching area of southwest Sarawak, Borneo, and was so far only found within the area of the Bako National Park, on the Bako Sandstone Plateau. This sandstone plateau is markedly different from the surrounding habitats, and is a unique area in Borneo. The nearby Gunung Santubong is part of the same sandstone formation as Bako, but it is much steeper without a plateau, and thus does not provide suitable habitat for Drosera.

Drosera spatulata var. bakoensis is common on the Bako Plateau in the Bako National Park, where it grows in open heath areas in pure white quartz sand, sometimes mixed with clay, but is never found in organic soils (see Figure 2). This sundew is only found where it is consistently very wet, i.e., adjacent to small creeks or seepages on embankments. Unlike $D$. burmannii Vahl, it seems to be very intolerant of even occasionally dry soils. Some of the trees in the open heaths, where D. spatulata var. bakoensis grows, are Ploiarium alternifolium Melchior (Theaceae), Cratoxylum glaucum Korth. (Clusiaceae) and Fagraea cuspidata Blume (Loganiaceae), but the Drosera seldom grow directly underneath them. Associated carnivorous

\footnotetext{
${ }^{1}$ The only other population of D. spatulata reported from Borneo is that from Marai Parai, Gunung Kinabalu, Sabah, which is about $850 \mathrm{~km}$ distant from Bako National Park (Van Steenis 1953). Taking into consideration our perspective that the Kinabalu Drosera is most likely not $D$. spatulata, but represent a different species, the nearest populations of D. spatulata var. spatula$t a$ that we can confirm are in west Malaysia (i.e., Kedah Peak (Van Steenis 1954) and Cameron Highlands (pers. observations, CCL), about $1050 \mathrm{~km}$ distant from Bako National Park.)
} 

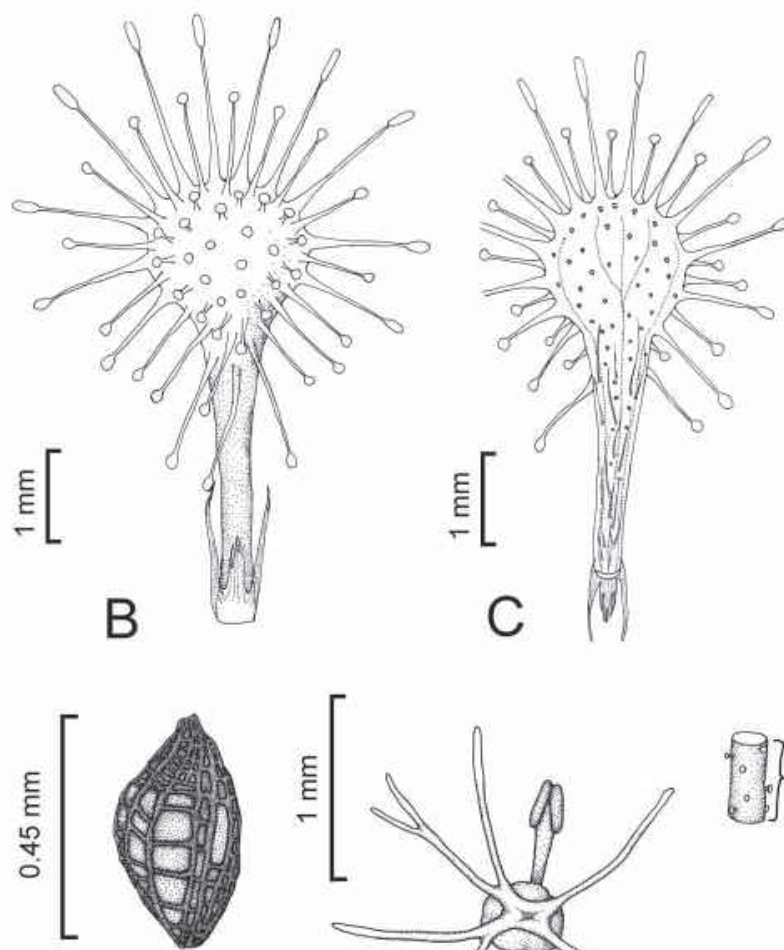

\section{$\mathrm{H}$}
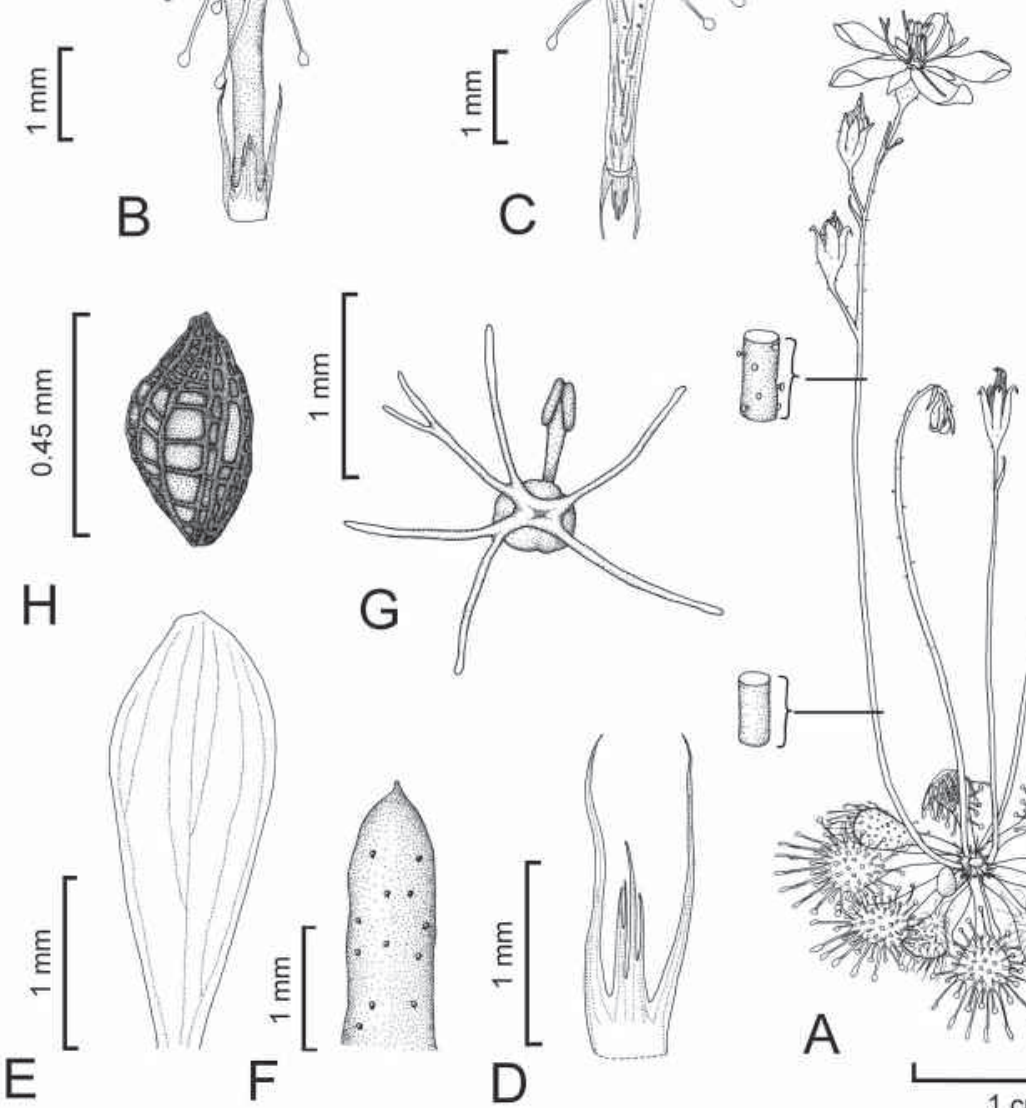

D
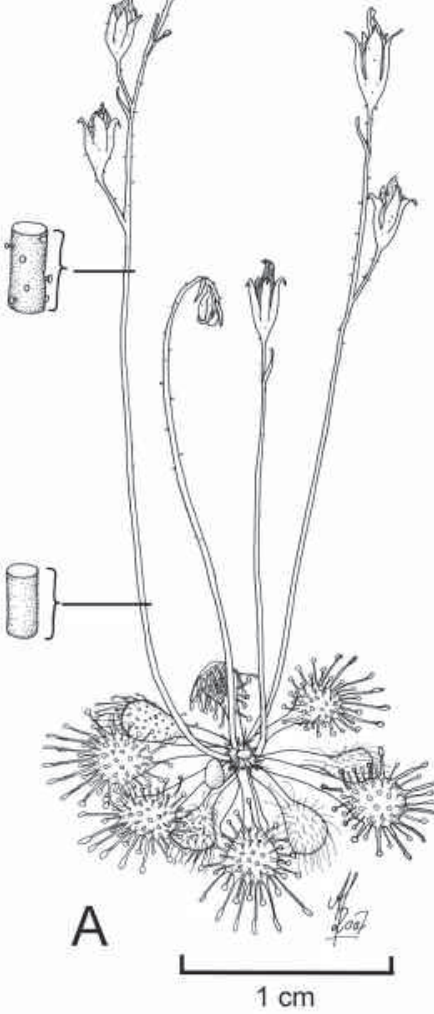

m

Figure 1: Line drawing of Drosera spatulata var. bakoensis. (A) Habit of plant in flower (with details of the peduncle surface near its base and middle), (B) leaf upper side, with attached stipule, (C) leaf lower surface, with the stipule bent back, (D) stipule, (E) detached petal, (F) sepal, (G) detail of the ovary, with one of the 5 anthers shown, and the three pairs of style arms - note the rare bifid tip of one of the style segments, $(H)$ seed. Drawing by Andreas Fleischmann. Size of the scale bars indicated. 
plants are Nepenthes albomarginata Lobb ex Lindl., N. ampullaria Jack, N. gracilis Korth., $N$. rafflesiana Jack, Utricularia caerulea L., U. hirta Klein ex Link, U. minutissima Vahl and U. uliginosa Vahl. Drosera burmannii Vahl has not been recorded from Bako, although it is common on nearby Gunung Matang and in Kuching (where D. spatulata is absent).

The annual rainfall at the park office area at Teluk Assam averages $4300 \mathrm{~mm}$, with a seasonal peak during the monsoon season (landas) from November to February. Extended dry periods in the dry season from May to September contribute to the harshness of the plateau environment. The temperatures are equatorial, ranging between $20^{\circ} \mathrm{C}$ and $32^{\circ} \mathrm{C}(\operatorname{Good} 1988)$.

\section{Discussion}

Drosera spatulata var. bakoensis (see Figures 3-5) differs from typical D. spatulata (as it is found in Australia, China and Japan for example; character values derived from our own observations are given in parentheses), in its distinctly petiolate leaves with broadly spatulate to rotundate lamina (cuneate to narrowly spatulate), the entire leaf being only $3-10 \mathrm{~mm}$ long (10-25 mm long). The stipules are $\approx 1 \mathrm{~mm}$ long, the two lateral lobes are about twice as long as the central lobe $(5-7 \mathrm{~mm}$ long, lateral lobes equally long or up to three times as long as central lobe). Scapes are 1-3-flowered, but occasionally with up to five flowers in exceptionally large specimens, like J. Carrick \& I.C. Enoch JC/49 (up to 20 flowers) and only sparsely glandular in the upper part, as are the pedicels and sepals (upper part of the scape, pedicels and sepals densely covered with short-stalked glands. (For a discussion of atypical plants from New Zealand that have glabrous sepals see the note below. A restricted population of D. spatulata in southeastern Queensland, Australia, with atypically short and hairy scapes has recently also been formally described as D. spatulata var. gympiensis (Gibson \& Snyder 2005).) The petals are elliptic to narrowly obovate, 5-6 $\mathrm{mm}$ long, up to $3 \mathrm{~mm}$ wide and pale pink (obovate to oblong, 3.0-3.5 mm long, $2 \mathrm{~mm}$ wide, colour white or pink).

Some populations of $D$. spatulata found in New Zealand have a leaf shape similar to D. spatulata var. bakoensis. This is especially true for the "alpine form" (Salmon 2001), i.e., the plants described as D. triflora Colenso

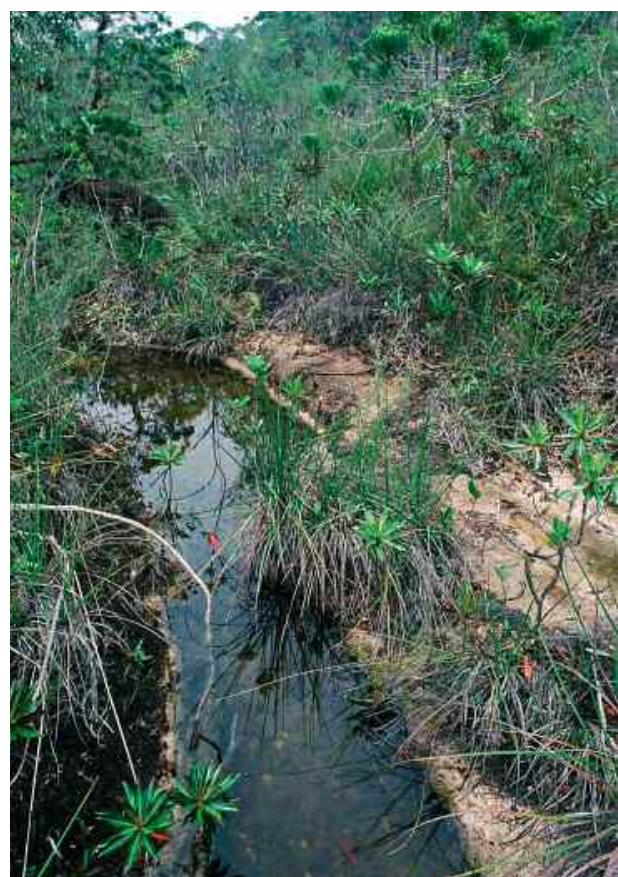

Figure 2: Typical habitat of Drosera spatulata var. bakoensis in Bako National Park. Photograph by Ch'ien Lee.

(Colenso 1890), which are similar to D. spatulata var. bakoensis in terms of size and number of flowers). However, the differences between the two sets of plants are as follows (New Zealand plants in parentheses): the base of the inflorescence scape is glabrous (lower 1/4 of the scape covered by simple white hairs), slightly glandular pedicels and upper third of the scape (pedicels and upper third of the scape glabrous), petals pale pink (petals white), and the stigmatic tips cylindrical and smooth to minutely papillate (clavate and papillate). The New Zealand populations of $D$. spatulata need further investigation and may deserve a distinct taxonomic classification. 

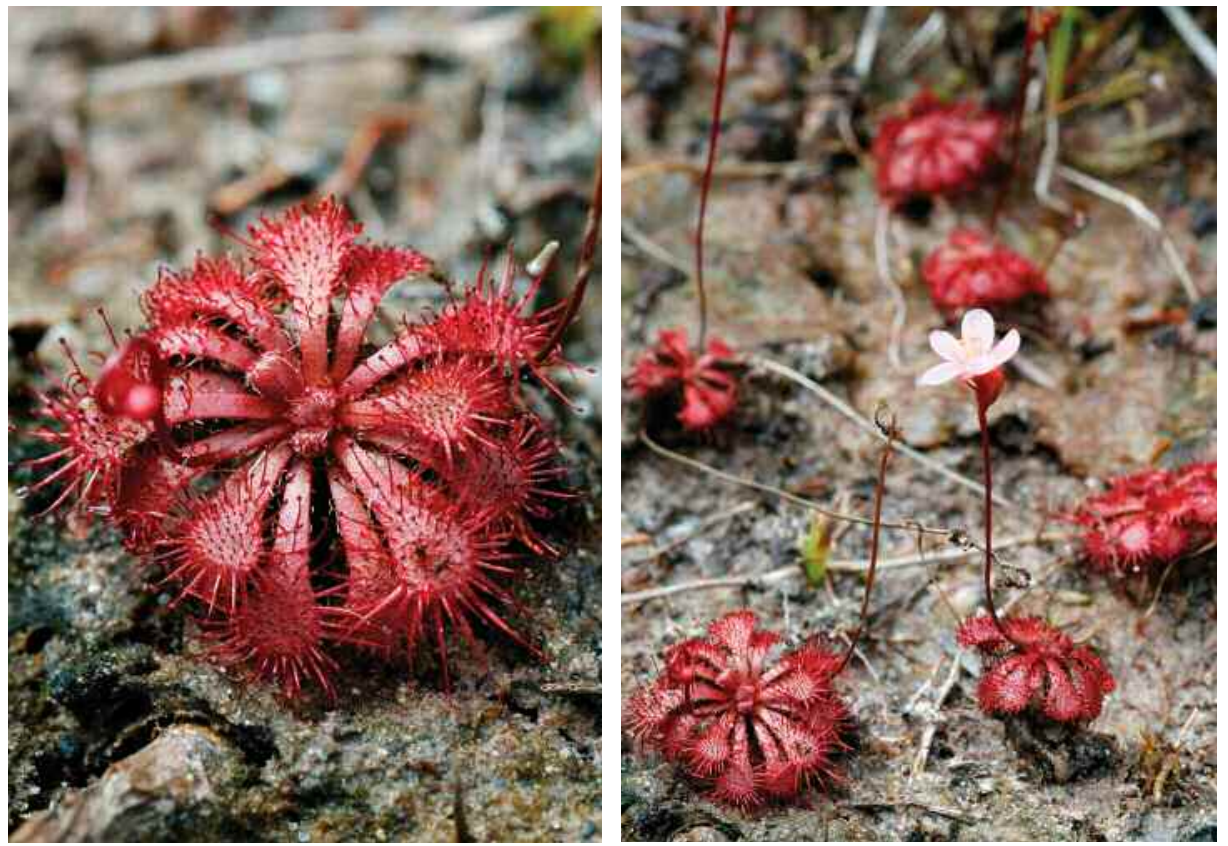

Figure 3: Close-up of a rosette of Figure 4: Group of D. spatulata var. D. spatulata var. bakoensis. Note the bakoensis in Bako National Park, Sarawak, distinctly petiolate leaves. Photograph by Borneo. Photograph by Ch'ien Lee. Ch'ien Lee.

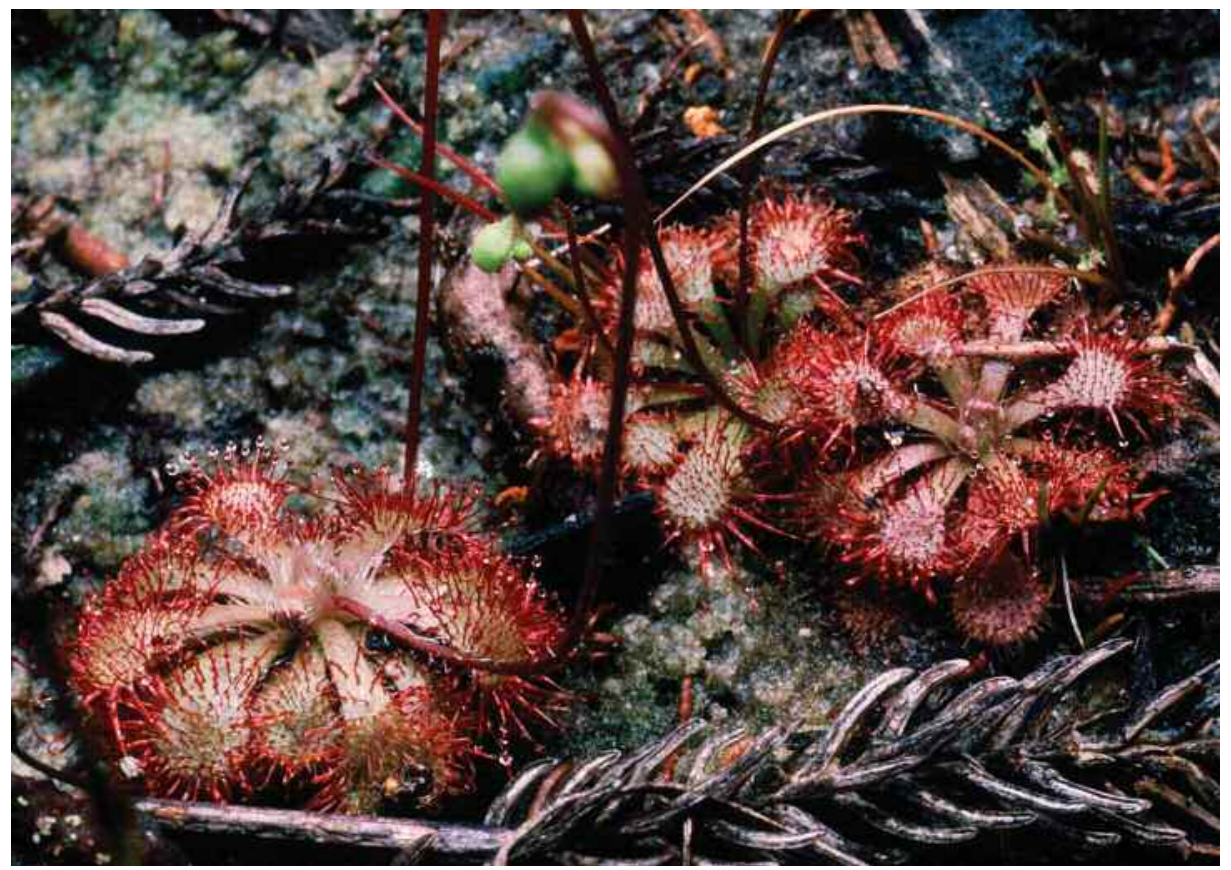

Figure 5: Plants of $D$. spatulata var. bakoensis growing in shaded locations have a less vividly red coloration. Photograph by Ch'ien Lee. 
In summary, this variety differs from typical $D$. spatulata in having a shorter scape with fewer flowers but larger petals, which are about twice as long as wide. The bases of the petals are not overlapping. Therefore, the sepals are clearly visible at anthesis when the flower is viewed from above (Figure 4).

\section{Acknowledgements}

The authors appreciate the kind assistance of Stewart McPherson, Dorset, England, Christian Klein, Merzig, Germany, and Anja and Holger Hennern, Bochum, Germany, for giving inspiring comments to the habitat description and supporting photographs of plants in the wild in Bako National Park, Borneo. Special thanks are also due to Thomas Carow for tracing back Harald Weiner's old sales lists, and to L.C.J. Julaihi of the Sarawak Herbarium for providing access to the specimens, as well as to a reviewer for helpful comments on the manuscript. No permits were required to conduct the work for this study.

References:

Colenso, W. 1890. A Description of some Newly-discovered Phænogamic Plants, being a Further Contribution towards the making-known the Botany of New Zealand [sic!].Trans. N. Zeal. Inst. 22: 459-493.

Gibson, R., and Snyder, I. 2005. Drosera spatulata var. gympiensis: the Formal Description of the "Hairy Sepal" Taxon from South-Eastern Queensland. Carniv. Pl. Newslett. 34: 56-60.

Good, L. 1988. Bako National Park: A Management Plan. Sarawak Forest Department, Kuching, Malaysia.

Hazebroek, H.P., and Morshidi, A.K.A. 2005. National Parks of Sarawak. Natural History Publications, Kota Kinabalu, Borneo.

Johansson, M. 1999. Facies analysis of the Plateau Sandstones (Eocene to early Miocene?), Bako National Park, Sarawak, Malaysia. Journal of Asian Earth Sciences 17: 233-246.

Salmon, B. 2001. Carnivorous Plants of New Zealand. Ecosphere Publications, Manuwera, New Zealand.

Tan, D.N.K. 1993. Geology of the Kuching Area West Sarawak, Malaysia. Geological Survey of Malaysia, Report 16, Kuching, Malaysia.

Van Steenis, C.G.G.J. 1953. Droseraceae. In: (eds.). Flora Malesiana.

Van Steenis, C.G.G.J. 1954. Miscellaneous botanical notes VI. Blumea 7: 595.

Weiner, H. 1982. Fleischfressende Pflanzen-Preisliste gültig bis März 82. Hameln, Germany.

\section{NEWS AND VIEWS}

Stephen Davis (stephen@carnivorousplants.org) writes: The California Academy of Sciences has reopened with much fanfare and has several exhibits featuring carnivorous plants. Geoff Wong and Stephen Davis designed and built a $3^{\prime} \times 3^{\prime} \times 4^{\prime}$ exhibit exclusively populated with CP. It features sphagnum moss walls with blooming Pinguicula from California Carnivores sown into them, and has nearly all genera of carnivorous plants represented. This display is temporary and is located downstairs among the tropical fish in the Steinhart Aquarium.

Judith Finn, Geoff, and Stephen put together two towering moss walls in the rainforest exhibit and covered them with Nepenthes and orchids. Sarracenia, when they aren't dormant, grace the edge of the albino alligator exhibit, and a small frog terrarium contains several species of carnivorous plants. There are also a few carnivorous plants on the moss wall in the cafeteria. Kristen Natoli is the first horticulturalist the Academy has had and has been a big advocate of the carnivorous plants and the displays. The California Academy of Sciences is located in Golden Gate Park in San Francisco. 